\title{
CONTEXT OF MIGRATION AND RECOGNITION OF EDUCATION
}

\section{[SOUVISLOST MIGRACE A UZNAVANI VZDELANI]}

\section{Dagmar Kostrhunova}

doi: 10.18355/PG.2021.10.2.5

\begin{abstract}
This contribution defines the conflicts that international migration brings in connection with the increased number of applicants for recognition of foreign education in the Czech republic. The migration of people has been increasingly observed since the so-called Arab Spring 2011 until now. Globalization or connecting the whole world is a current trend that people are learning to accept. Each country receiving migrants determines its own strategy, rules, and approach to migration. ,It is estimated that today about 150 million people live outside their homeland" (Siskova, 2001: 18). With the increased migration and globalization, there has been an increased number of applicants in the Czech Republic for the recognition of education, serving mainly for further higher education. At the same time, for gaining job opportunities, for using foreign experience and, last but not least, for finding better living conditions. „The main determinants of human movements can be considered differences in the wealth of individual economies, living standards and stability in given societies" (Siskova, 2001: 19).

The aim of the contribution is to get acquainted with the basic concepts of migration and migration policy in connection with the recognition of education in the Czech Republic from foreign countries and whether increased migration of persons related to the recognition of foreign education and the acquisition of further education of foreigners in the Czech Republic.
\end{abstract}

\section{Key words}

Conflict, crisis, migration, immigration, international, education, recognition, laws, applicants

\section{Anotace}

Tento příspěvek je zaměřen na konflikty, které přináší mezinárodní migrace v návaznosti na zvýšený počet žadatelů o uznání zahraničního vzdělání v ČR (České republice). Migrace osob je ve zvýšené míře pozorována od tzv. Arabského jara 2011 dosud. Globalizace, nebo-li propojení celého světa je současný trend, který se lidé učí akceptovat. Každá země přijímající migranty určuje vlastní strategie, pravidla a přístup k migraci. „Odhaduje se, že dnes žije asi 150 milionů lidí mimo svoji mateřskou vlast" (Siskova, 2001: 18). Se zvýšenou migrací a globalizací je v ČR zaznamenám zvýšený počet žadatelů o uznání vzdělání sloužícího především pro další vyšší vzdělávání. Zároveň také pro získání pracovních příležitostí, pro využití zahraničních zkušeností a v neposlední řadě hledání lepších podmínek pro život. „Za hlavní determinanty pohybi̊ osob je možno považovat rozdilnost $v$ bohatství 
jednotlivých ekonomik, životní úrovně a stability v daných společnostech “ (Siskova, 2001: 19) .

Cílem př́íspěvku je seznámit se základními pojmy migrace, migrační a imigrační politiky $\mathrm{v}$ souvislosti $\mathrm{s}$ uznáváním vzdělání v ČR $\mathrm{z}$ cizích zemí včetně vývoje počtu žádostí o uznávání vzdělání v ČR a jestli má zvýšená migrace osob souvislost $\mathrm{s}$ uznáváním zahraničního vzdělání a získáváním dalšího vzdělání cizinců v ČR.

\section{Klíčová slova}

Konflikt, krize, migrace, imigrace, mezinárodní, vzdělávání, uznávání, zákony, žadatelé

\section{ÚVOD}

Nosným a vysoce aktuálním tématem současnosti je migrace osob do Evropských zemí. Je mnoho osob, které migrují z jedné země do druhé $\mathrm{z}$ mnoha důvodů. Jednak jsou to důvody poznávání různých kultur a jazyků, důvody získávání zahraničního vzdělání v cizí zemi, výhodnější geografické podmínky a v neposlední řadě jsou to důvody ekonomické - hledání vyšší kvality života.

Migrace je stará jako lidstvo. V historii bylo více migračních vln a různá osídlování území. Mluví se o tzv. Biblickém Exodu, kdy židé utíkali z egyptského zajetí. Tento Exodus je považován za nejstarší migrační vlnu a datuje se do 13. století př̀. n.l. ${ }^{1}$ Židovský národ potřeboval svobodu a usadil se na území současného Izraele. K dalšímu stěhování národů došlo při rozpadu Římské říše, která byla napadena barbarskými kmeny Vandalů, což vedlo $\mathrm{k}$ jejímu pádu a zároveň ke stěhování národů. Tento proces je datován od 3. do 6. století. ${ }^{2}$ Turci v 15. století dobyli Byzantskou říši, což vyvolalo rozsáhnou emigraci do západních zemí. ${ }^{3}$ Dále v 15 . století dochází $\mathrm{k}$ vyhnání Židů a muslimů ze Španělska z náboženských důvodů (katolíci). Zemi bylo nuceno opustit statisíce lidí. Přijala je Osmanská říše, protože toto obyvatelstvo považovala za ekonomicky prospěšné. ${ }^{4}$ Objevením Ameriky Kryštofem Kolumbem roku 1541 začínala velká migrace evropských obyvatel na „nový“ kontinent. V polovině 19. století donutil velký hladomor obyvatele Irska k hromadnému stěhování do Ameriky. A v neposlední řadě je velká migrace spojena $\mathrm{s}$ obdobím před 2 . světovou válkou a týkala se především Židů. ${ }^{5}$ Odhaduje se, že nejbohatší země světa mají na svých územích asi jednu třetinu světové populace imigrantů. V zemích západní

\footnotetext{
${ }^{1}$ https://epochaplus.cz/7-nejvetsich-migracnich-vln-v-historii-odveka-honba-za-lepsibudoucnosti/

${ }^{2}$ ZAMAROVSKÝ, V. Dějiny psané Římem, s. 252

${ }^{3}$ https://epochaplus.cz/7-nejvetsich-migracnich-vln-v-historii-odveka-honba-za-lepsibudoucnosti/

https://epochaplus.cz/7-nejvetsich-migracnich-vln-v-historii-odveka-honba-za-lepsi-

budoucnosti/

https://epochaplus.cz/7-nejvetsich-migracnich-vln-v-historii-odveka-honba-za-lepsi-
}

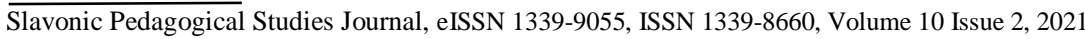


Evropy se na konci devadesátých let 20. století nacházelo více než dvacet milionů imigrantů (Šišková, 2001 s. 18). V devadesátých letech 20. století migrovali do České republiky (ČR) lidé z bývalých sovětských republik především z ekonomických důvodů (Trbola, Rákoczyová, 2010, p. 10) a osoby a oběti konfliktu z bývalé Jugoslávie (Šišková, 2008: 67). V rámci globalizace došlo ke zvýšenému počtu aktérů, kteří se podílí na tvorbě vlastní politiky ve svých zemích [Šišková, 2001, s. 20]. Každá země světa má svoji kulturu a národní zvyky a imigrací svých národních kultur přináší danému státu určitou změnu života a nutnost přizpůsobování se. Následkem zvýšené migrace od roku 2015 si Evropa zvyká a přizpůsobuje svoje opatření i zákony $\mathrm{k}$ eliminaci konfliktů plynoucích z migračních vln.

Po roce 2001 je pozorován v ČR zvýšený nárůst žádostí o uznávání vzdělání z cizích zemí, a to především uznávání středního vzdělání pro účely studia na českých univerzitách. ${ }^{6}$ „Většina zemí světa má snahu o rozvoj národního hospodářství, zároven také o rozvoj vzdělávání mladé generace i dospělých, protože prosperita populace závisí ve velké míre na vzděláni" (Průcha, 2017, p. 9). Uznávání zahraničního vzdělávání základního, středního a vy̌ššího odborného vzdělání mají v přenesené působnosti za Ministerstvo školství, mládeže a tělovýchovy (MŠMT) krajské úřady. Uznávání vzdělání se řídí zákonem č. 561/2004 Sb., o předškolním, stř̌edním, vyšším odborném a jiném vzdělávání (Školský zákon). Podle $\S 108$ může požádat absolvent zahraniční školy o vydání osvědčení o uznání rovnocennosti zahraničního vysvědčení v České republice anebo může požádat o rozhodnutí vydání platnosti zahraničního vzdělání (nostrifikace). ${ }^{7}$ A podle $\S 108$ a) odst. 4 může požádat o uznání vzdělání i osoba, již byla poskytnuta mezinárodní ochrana. ${ }^{8}$ Největší počet žadatelů je $\mathrm{v}$ krajích, kde je vyšší počet univerzit - hlavní město Praha a Jihomoravský kraj. Nejvyšší počet žádostí je od žadatelů z bývalých sovětských republik (především Ukrajina, Rusko, Bělorusko), ale také ze zemí Sýrie, Irán, Irák, afrických zemí a další žadatelé jsou z členských zemí Evropské unie (EU).

Cílem tohoto př́spěvku je seznámit se souvislostmi globální migrace a uznávání zahraničního vzdělání. Migrace, emigrace i imigrace ovlivňuje žadatele, kteří chtějí uznat vzdělání právě v ČR. První část příspěvku se zabývá teorií ohledně migrace a druhá část př́íspěvku sleduje vývoj počtu žádostí o uznání zahraničního vzdělání na krajských úřadech v ČR. Součástí př́spěvku je vlastní průzkum.

\footnotetext{
${ }^{6}$ KOSTRHU゚NOVÁ, D. 2014. Uznávání zahraničního vzdělání. Př́spěvek přednesený na 3.(8) ročníku mezinárodní konference CALL FOR PAPERS konané pod záštitou rektora Vysoké školy Karla Engliše. ISBN 978-80-86710-80-8.

${ }^{7}$ KOSTRHƯNOVÁ, D. 2014. Uznávání zahraničního vzdělání. Př́ispěvek přednesený na 3.(8) ročníku mezinárodní konference CALL FOR PAPERS konané pod záštitou rektora Vysoké školy Karla Engliše. ISBN 978-80-86710-80-8.

${ }^{8}$ Zákon č. 561/2004 Sb., o předškolním, základním, středním, vyšším odborném a jiném vzdělávání (Školský zákon), §108 a), odst. 4.
} 


\section{MIGRACE, EMIGRACE, IMIGRACE, MIGRAČNÍ POLITIKA}

Migrace osob do Evropy je ve zvýšené míře pozorována asi 10 roků od tzv. Arabského jara 2011 dosud. Jedná se o konflikty v arabském světě (Tunisko, Alžírsko, Egypt, Jemen, Libye, Maroko, Sýrie, Saudská Arábie a další země). ${ }^{9} \mathrm{~V}$ zemích Severní Afriky a v blízkovýchodních zemích docházelo ke změnám režimu, reformám i občanským válkám. Z tohoto důvodu evropské země, kterých se týkala zvýšená imigrace, nastavily migrační politiku.

Aktivní migrační politika doprovázená integračními snahami je jevem, bez něhož se v budoucnu neobejde žádná vyspělá země. Výjimkou není ani ČR, která zareagovala na nárůst imigračních toků již po roce 1990 nejprve aplikováním imigrační politiky a teprve po 20 letech ji doplnila snahou o růst integračních opatření (Rákoczyová, Trbola, 2008: 29).

\subsection{Migrace}

Migrace je přesun osob $\mathrm{z}$ jedné země do druhé $\mathrm{z}$ různých důvodů. $\mathrm{Z}$ ekonomických, $\mathrm{z}$ důvodu nestability země, $\mathrm{z}$ důvodů studijních, $\mathrm{z}$ důvodů poznat jiné kultury. „Migrace je presun jednotlivců i skupin v prostoru, který je spolu s porodností a úmrtností klíčovým prvkem v procesu populačního vývoje a výrazně ovlivňuje společenské a kulturní změny obyvatel na všech úrovních. “10

Rozdělení migrace

- Nucená

- Dobrovolná

- Vnitrostátní

- Mezinárodní

- Ekonomická

- Právní

- Humanitární

- Náboženská ${ }^{11}$

Kategorie rozdělení migrace ukazují příčinu migrace. Bud' jsou lidé nuceni opustit svoji zem anebo dobrovolně chtějí žít v jiném státě. Bud' migrují v rámci své země anebo migrují do jiné země světa. Ekonomická migrace znamená stěhovat se za lepšími podmínkami života. V případě porušování lidských práv se mluví o migraci právní. Jako humanitární program je

\footnotetext{
9 https://www.e15.cz/zahranicni/od-revoluci-arabskeho-jara-uplynulo-deset-let-zklamaly-lidemse-zije-jeste-hur-1376360

${ }^{10}$ Pražský studentský summit/XX/EU/I. Asociace pro mezinárodní otázky pro potřeby XX. ročníku Pražského studentského summitu. Imigrace na území EU. AMO 2014.

${ }^{11}$ Pražský studentský summit/XX/EU/I. Asociace pro mezinárodní otázky pro potřeby XX. ročníku Pražského studentského summitu. Imigrace na území EU. AMO 2014.
} 
poskytování lékařské péče zranitelným skupinám uprchlíkủ. ${ }^{12}$ Lidé v některých zemích světa nemohou svobodně vyznávat náboženství, proto opouštějí svoji zemi a migrují do země, kde je jim tato svoboda umožněna. Nejrozšířenějším typem migrace je migrace ekonomická, tedy migrace za prací. $^{13}$

\subsection{Emigrace}

Emigrace je označována jako vystěhování se do jiného místa trvale nebo dočasně. ${ }^{14} \mathrm{~V}$ př́ípadě návratu emigranta je používán termín reemigrace. Jde-li o početné přesuny a následné změny, které mohou významně ovlivňovat strukturu místní populace, existuje snaha tyto pohyby usměrňovat nebo regulovat. ${ }^{15}$ Některé státy zákonem omezují počet a demografickou, sociální či etnickou strukturu přistěhovalcủ.

Rozdělení emigrace

- Dobrovolná

- Nedobrovolná

„Emigrace nemusí být vždy výsledkem svobodného rozhodnuti. “16 Lidé emigrují na základě různých konfliktních situací vzniklých ve své vlasti. Například v ohrožení vlastních životů, z politických důvodů, etnických důvodů nebo $\mathrm{z}$ náboženské nesnášenlivosti a to dobrovolně nebo nedobrovolně.

\subsection{Imigrace}

Imigrace je přistěhovalectví. Opakem emigrace. Pokud imigranti přicházejí ze země s nízkou životní úrovní, s nižší úrovní vzdělání, z jiné kultury, může docházet $\mathrm{k}$ problému $\mathrm{s}$ jejich zapojením se do majoritní společnosti. Imigraci cizinců podporuje zvýšená mobilita pracovních sil i volný pohyb osob (Šišková, 2008, p. 75). Někteří z nich se nedokážou přizpůsobit nové společnosti a vytváří uzavřené společnosti s vlastní kulturou země, ze které přicházejí.

V současnosti je otázka imigrace velmi často řešena $\mathrm{z}$ důvodu zvýšeného počtu imigrantů do ČR. Po pádu ,železné opony“ a v dalších letech nejvíce po roce 2000 je statisticky evidováno 209 tisíc imigrantů. Velká většina těchto imigrantů byla z postsovětských zemí. Jednalo se o legální i nelegální imigraci většinou $\mathrm{z}$ pracovních důvodů. ${ }^{17}$

\subsection{Migrační politika}

\footnotetext{
${ }^{12}$ https://www.mvcr.cz/migrace/clanek/zdravotne-humanitarni-program-medevac.aspx

${ }^{13} \mathrm{https}: / / \mathrm{www}$.inkluzivniskola.cz/o-migraci

${ }^{14} \mathrm{https}: / /$ encyklopedie.soc.cas.cz/w/Emigrace

${ }^{15} \mathrm{https}$ ://encyklopedie.soc.cas.cz/w/Emigrace

${ }^{16}$ https://www.inkluzivniskola.cz/o-migraci

${ }^{17} \mathrm{https}: / /$ journals.muni.cz/cepsr/article/view/4040/5278
} 
Zodpovědnost na úseku migrační politiky v ČR má Ministerstvo vnitra ČR (MV ČR), odbor azylové a migrační politiky. Řídí se zákonem č. 326/1999 Sb., o pobytu cizinců na území ČR. ČR klade důraz na bezpečnostní aspekty migrace. ${ }^{18}$ Mezi nejdůležitější aspekty migrační politiky patří integrování cizinců, legální i nelegální migrace, mezinárodní ochrana, azylová politika včetně volného pohybu osob v rámci Evropské unie (EU) a schengenského prostoru včetně ochrany hranic a bezpečnosti státu. ${ }^{19}$ Strategie ČR v rámci migrační politiky vede $\mathrm{k}$ posilování pozitivní migrace osob a k potírání negativních jevů s migrací spojených. ${ }^{20}$

Dalším typem mezinárodní migrace je získání studijního víza pro účely studia $\mathrm{v}$ ČR. Pro tyto účely je nutný platný cestovní doklad a potvrzení o přijetí ke studiu, odborné praxi či dobrovolné službě. ${ }^{21}$ Studium musí probíhat na střední škole, vyšší odborné škole, konzervatoři na základě školského zákona č. 561/2004 Sb., nebo vakreditovaných studijních programech na vysoké škole podle zákona č. 111/1998 Sb., o vysokých školách. Také se může jednat o účast na jazykové a odborné přípravě ke studiu akreditovaného studijního programu vysoké školy organizované veřejnou vysokou školou nebo stipendijní pobyt. ${ }^{22}$

\section{Tabulka č. 1 Počet cizinců na území ČR v letech 2019 a 2020}

\begin{tabular}{|c|l:c|l|c|c|c|c|}
\hline \multicolumn{3}{|c|}{ Rok 2019 } & \multicolumn{3}{c|}{ Rok 2020 } \\
\hline $\begin{array}{c}\text { Země } \\
\text { EU }\end{array}$ & $\begin{array}{l}\text { Cizinci } \\
\text { z }\end{array}$ & $\begin{array}{c}\text { z toho: } \\
\text { bývalé } \\
\text { třetích } \\
\text { sovětské } \\
\text { zemí }\end{array}$ & Cellkem & $\begin{array}{c}\text { Země liky } \\
\text { EU }\end{array}$ & $\begin{array}{c}\text { cizinci } \\
\text { z } \\
\text { třetích } \\
\text { zemí }\end{array}$ & $\begin{array}{c}\text { z toho: } \\
\text { bývalé } \\
\text { sovětské } \\
\text { republiky }\end{array}$ & Celkem \\
\hline 246 & 349 & 185000 & 595881 & 243 & 390 & 218701 & 634790 \\
321 & 560 & 837 & 933 & \\
\hline
\end{tabular}

Zdroj: vlastní zpracování Statistické př́lohy Ministerstva vnitra ${ }^{23}$

V Tabulce č. 1 Počet cizinců na území ČR v letech 2019 a 2020 ukazuje, že v roce 2019 bylo na území ČR 595881 cizinců a v roce 2020 to bylo 634790 cizinců. Celkový nárůst počtu cizinců je $6,1 \%$ v roce 2020. Mezi migranty z třetích zemí jsou řazeni Ukrajinci, Rusové, Vietnamci, Mongolové, Číňané, Bělorusi, Indi a další. Nejpočetnější skupinou jsou lidé z bývalých

\footnotetext{
${ }^{18} \mathrm{https}: / /$ www.mvcr.cz/migrace/clanek/obecne-o-migracni-a-azylove-politice-ceske-republikyobecne-o-migracni-a-azylove-politice-ceske-republiky.aspx

${ }^{19} \mathrm{https} / / / \mathrm{www} . \mathrm{mvcr} . c z / m i g r a c e / c l a n e k /$ strategie-migracni-politiky-ceske-republiky.aspx

${ }^{20} \mathrm{https}: / / \mathrm{www} . \mathrm{mvcr} . \mathrm{cz} / \mathrm{migrace} / \mathrm{clanek} /$ zasady-migracni-strategie.aspx

${ }^{21} \mathrm{https}: / / \mathrm{www} . \mathrm{mvcr} . c z / c l a n e k /$ informace-pro-skoly.aspx?q=Y2hudW09NQ\%3D\%3D

${ }^{22} \mathrm{https}: / / \mathrm{www} . \mathrm{mvcr} . c z / c l a n e k /$ informace-pro-skoly.aspx?q=Y2hudW09NQ\%3D\%3D

${ }^{23}$ file:///C:/Users/kostrhunova.dagmar/Downloads/Ctvrtletni_zprava_o_migraci_IV-Q_2020__priloha\%20(1).pdf
} 
sovětských republik (v roce 2019 to je 185 tisíc občanů a v roce 2020 to je 218701 občanů), což je nárůst o 18,2 \% více migrantů oproti roku 2019. Tomu odpovídá i to, že největší počet žadatelů o uznání vzdělání je z bývalých sovětských republik (Tabulka č. 2 Počet žadatelů o uznání vzdělání v ČR). Dále v Tabulce č. 1 Počet cizinců na území ČR v letech 2019 a 2020 ve sloupci cizinci z trêtích zemí je vidět nárůst o $11,8 \%$ v roce 2020 oproti roku 2019.

\section{UZNÁVÁNí VZDĚLÁNí}

Uznávání středního nebo vyššího odborného vzdělání občanů získaného $\mathrm{v}$ cizích zemích vykonávají krajské úřady $\mathrm{v}$ přenesené působnosti za Ministerstvo školství, mládeže a tělovýchovy (MŠMT). Uznávání ukončeného vysokoškolského vzdělání ze zahraničí uznávají př́́slušné univerzity podle oborů vzdělání na základě zákona č. 111/1998 Sb. o vysokých školách.

\subsection{Náležitosti žádosti $k$ uznání stř̌edního nebo vyššího odborného vzdělání v ČR}

Proces uznávání zahraničního vzdělání získaného na zahraničních školách definuje $§ 108$ školského zákona. Žadatelé podávají žádost na krajském úřadě [Zákon č. 500/2004 Sb., Správní řád, § 11]. Žadatel předkládá doklady o uceleném stupni vzdělání - o ukončení základní školy, o středním odborném učilišti, o střední všeobecně vzdělávací škole, o střední odborné škole, o vyšší odborné škole. „K žádosti se současně prípojí úředně ověrený překlad dokladi̊ do českého jazyka" [Školský zákon, § 108, odst. 4]. „Pokud mezinárodní smlouva, kterou je ČR vázána, nestanoví jinak, pravost podpisu a otiskü razitek na originálech zahraničnich vysvědčení a skutečnost, že škola je uznána státem, podle jehož právního rádu bylo zahranični vysvědčení vydáno, musí být ověřna př̀islušným zastupitelským úradem České republiky a dále ministerstvem zahraničních věci státu, podle jehož právního řádu bylo zahranični vysvědčení vydáno. "24

Jedná se o dva typy legalizace dokladů. Bud' razítko z Ministerstva zahraničních věcí př́slušného státu, kde žadatel studoval - APOSTILLA (jedno razítko) anebo superlegalizace - Ministerstvo zahraničních věcí a Česká ambasáda př́slušné země, kde žadatel studoval (dvě razítka) (Čižinský, 2014: 5-7).

\subsection{Doklady o vzdělání z cizí země}

\footnotetext{
${ }^{24}$ KOSTRHƯNOVÁ, D. 2014. Uznávání zahraničního vzdělání. Př́íspěvek přednesený na 3.(8) ročníku mezinárodní konference CALL FOR PAPERS konané pod záštitou rektora Vysoké školy Karla Engliše. ISBN 978-80-86710-80-8.
} 
Doklady, které žadatelé předkládají na krajských úřadech v ČR k uznání svého vzdělání ze zahraničí.

- Diplom, maturitní vysvědčení, výuční list (ověřené kopie s překladem do českého jazyka)

- Obsah a rozsah vzdělání ze zahraniční školy

- Ž́ádost

- Zaplacení správního poplatku

\subsection{Výjimky - mezinárodní ochrana}

Mezinárodní ochrana je poskytována občanům, kteří se ve své vlasti cítí ohroženi z mnoha důvodů. Mezinárodní ochranu poskytují země dle vlastních pravidel, kde žadatel podá žádost o mezinárodní ochranu a podá odůvodnění své žádosti. Jedná se o udělení azylu nebo doplňkové ochrany.

V př́ípadě uznávání vzdělání osob s mezinárodní ochranou, které žádají o uznání vzdělání, školský zákon v § 108 a) odst. 4 přesně definuje, jaké doklady tento žadatel musí předložit anebo může tyto dokumenty nahradit čestným prohlášením. ${ }^{25}$

Azyl je poskytován osobám z důvodu pronásledování z politických důvodů, ohrožení práv a svobod, z odůvodněného strachu z pronásledování, z důvodu rasy, pohlaví, náboženství, národnosti anebo za účelem sloučení rodiny. ${ }^{26}$ Azyl spolu s doplňkovou ochranou souvisí s mezinárodní ochranou osob a Česká republika jako člen EU je vázána ke spolupráci. ${ }^{27}$

Doplňková ochrana je poskytována žadatelům v př́ipadě, že nejsou zjištěny v dostatečné míre azylové důvody, ale žadatel prokáže, že by mu v jeho zemi hrozilo nebezpečí trestu smrti, mučení nebo nelidské či ponižující zacházení nebo trestání. Doplňková ochrana může být též udělena $\mathrm{z}$ důvodu sloučení s rodinným př́íslušníkem, kterému již byla doplňková ochrana udělena. ${ }^{28}$

\section{VÝVOJ UZNÁVÁNÍ VZDĚLÁNí}

V roce 2014 byl proveden průzkum počtu žádostí o uznání vzdělání v jednotlivých krajích ČR a bylo zjištěno, že od roku 2005 je sledován nárůst počtu žadatelů o uznání středního vzdělání v ČR. Největší počet žadatelů je $z$ bývalého Sovětského svazu, ale i jiných zemí Evropy i světa. Zatímco v roce 2001 byl celkový počet žádostí ze všech krajů 818, v dalších letech od roku 2005 až po rok 2013 byl počet žádosti vyšší o 3718 žádostí, což činilo $455 \%$

\footnotetext{
25 Zákon č. 561/2004 Sb., o předškolním, základním, středním, vyšším odborném a jiném vzdělávání (Školský zákon), \$108 a), odst. 4.

${ }^{26}$ Zákon č. 325/1999 Sb., Zákon o azylu § 12, § 13.

27 https://www.mvcr.cz/migrace/clanek/nase-hlavni-temata-mezinarodni-ochrana-mezinarodniochrana.aspx

${ }^{28} \mathrm{https}$ ///www.migrace.com/cs/poradna/informace-pro-cizince/zadatele-o-mezinarodni-ochranu

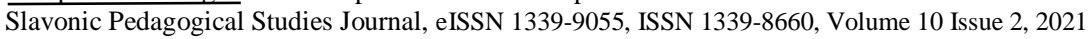


navýšení počtu žádostí o uznání zahraničního vzdělání na všech krajích v ČR celkem. $^{29}$

Pro účely tohoto článku byly v lednu 2021 písemně osloveny všechny krajské úrady ČR. Byly zjišt'ovány informace o počtu žádostí o uznání vzdělání (nostrifikace) za období roku 2019 a roku 2020. Dále bylo zjišt'ováno rozdělení dle zemí (bývalé sovětské republiky, země EU a ostatní země). Sběr dat probíhal během měsíce ledna 2021 na všech krajích ČR (viz Tabulka č. 2. Počet žadatelů o uznání vzdělání v ČR).

Tabulka č. 2 Počet žadatelů o uznání vzdělání v ČR

\begin{tabular}{|c|c|c|c|c|c|c|c|c|c|}
\hline & \multicolumn{4}{|c|}{ Rok 2019} & \multicolumn{3}{|c|}{ Rok 2020} & \multirow[b]{2}{*}{ 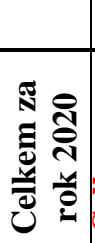 } & \multirow[b]{2}{*}{ 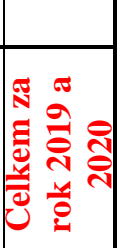 } \\
\hline Kraje ČR & 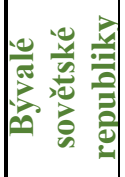 & 里 & 恶 & 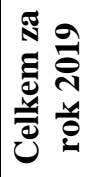 & 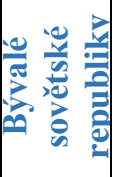 & D્1 & 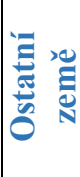 & & \\
\hline $\begin{array}{l}\text { Magistrát } \\
\text { hlavního města } \\
\text { Prahy }\end{array}$ & 2450 & 645 & 405 & 3500 & 1855 & 560 & 235 & 2650 & 6150 \\
\hline Středočeský kraj & 867 & 96 & 94 & 1057 & 835 & 111 & 52 & 998 & 2055 \\
\hline Jihočeský kraj & 204 & 4 & 6 & 214 & 100 & 8 & 7 & 115 & 329 \\
\hline Plzeňský kraj & 138 & 10 & 9 & 157 & 95 & 8 & 11 & 114 & 271 \\
\hline Karlovarský kraj & 179 & 7 & 47 & 233 & 151 & 5 & 23 & 179 & 412 \\
\hline Ústecký kraj & 108 & 3 & 7 & 118 & 102 & 3 & 8 & 113 & 231 \\
\hline Liberecký kraj & 219 & 8 & 5 & 232 & 123 & 4 & 5 & 132 & 364 \\
\hline $\begin{array}{l}\text { Královehradecký } \\
\text { kraj }\end{array}$ & 272 & 113 & 11 & 396 & 108 & 66 & 18 & 192 & 588 \\
\hline Pardubický kraj & 123 & 7 & 1 & 131 & 131 & 2 & 1 & 134 & 265 \\
\hline Kraj Vysočina & 39 & 5 & 3 & 47 & 27 & 4 & 1 & 32 & 79 \\
\hline $\begin{array}{l}\text { Jihomoravský } \\
\text { kraj }\end{array}$ & 1135 & 36 & 141 & 1312 & 1152 & 38 & 83 & 1273 & 2585 \\
\hline Olomoucký kraj & 23 & 2 & 12 & 37 & 24 & 6 & 3 & 33 & 70 \\
\hline $\begin{array}{l}\text { Moravskoslezský } \\
\text { kraj }\end{array}$ & 179 & 37 & 18 & 234 & 133 & 25 & 17 & 175 & 409 \\
\hline Zlínský kraj & 26 & 1 & 3 & 30 & 9 & 8 & 4 & 21 & 51 \\
\hline
\end{tabular}

\footnotetext{
${ }^{29}$ KOSTRHU゚NOVÁ, D. 2014. Uznávání zahraničního vzdělání. Příspěvek přednesený na 3.(8) ročníku mezinárodní konference CALL FOR PAPERS konané pod záštitou rektora Vysoké školy Karla Engliše. ISBN 978-80-86710-80-8.
} 


\begin{tabular}{|l|l|l|l|l|l|l|l|l|l|} 
Kraje celkem & 5962 & 974 & 762 & $\mathbf{7 6 9 8}$ & 4845 & 848 & 468 & $\mathbf{6 1 6 1}$ & $\mathbf{1 3 8 5 9}$ \\
\hline
\end{tabular}

Pramen: vlastní zpracování podle průzkumů v jednotlivých krajích ČR

Z Tabulky č. 2. Počet žadatelů o uznání vzdělání v ČR vyplývá, že se jedná o všech 13 krajů ČR a Magistrát hlavního města Prahy. Z tabulky je vidět skutečnost, že nejvyšší počet žádostí je $\mathrm{z}$ bývalých sovětských republik $\mathrm{v}$ obou zkoumaných letech 2019, 2020. Dále je vidět, že nejvyšší počet žádostí je v Praze (Středočeský kraj a Magistrát hlavního města Praha) a v Brně (Jihomoravský kraj), což jsou univerzitní města a většina těchto žadatelů uznává svoje zahraniční vzdělání především z důvodu studia na českých univerzitách.

V roce 2005 bylo podáno 1669 žádostí celkem na všech krajích. ${ }^{30} \mathrm{~V}$ roce 2019 bylo podáno 7698 žádostí (viz Tabulka č. 2), což představuje nárůst počtu žádostí o uznání vzdělání o $461 \%$ oproti roku 2005. V roce 2020 bylo podáno 6161, jedná se taktéž o velký nárůst $369 \%$ oproti roku 2005. Ale v porovnání roku 2019 s rokem 2020 je zaznamenáno v roce 2020 snížení počtu žádostí o 1537 žádostí. Pravděpodobnost sniženého počtu žádostí bylo uzavřením hranic i „nebe“ $\mathrm{z}$ důvodu onemocnění Covid-19. Rozdíl mezi jednotlivými kraji je také značný. Nejnižší počet žádostí je v Kraji Vysočina, v Olomouckém a Zlínském kraji (desítky žádostí) oproti ostatním krajům se stovkami žádostí. Dalším zjištěním je skutečnost, že žadatelé z bývalých sovětských republik podávají nejvíce žádostí oproti žadatelům ze zemí EU a zemí ostatních. $Z$ celkového počtu žádostí o uznání vzdělání (nostrifikace) v roce 2019 činí 77 \% žádostí z bývalých sovětských republik, žadatelů ze zemí EU je z celkového počtu $13 \%$ a z ostatních zemí je počet žadatelů 10 $\%$. V roce 2020 je $78 \%$ žádostí od žadatelů z bývalých sovětských republik (mírné navýšení oproti roku 2019), žadatelů ze zemí EU je 14 \% (mírné navýšení oproti roku 2019) a žadatelů z ostatních zemí světa je pouze $8 \%$ (mírné snížení oproti roku 2019) z celkového počtu podaných žádostí.

\section{1 Žadatelé s mezinárodní ochranou}

Na krajských úřadech žádají o uznání vzdělání i žadatelé s uděleným azylem anebo s poskytnutou doplňkovou ochranou. Jedná se o jednotlivce. V Jihomoravském kraji v roce 2019 nežádal o uznání vzdělání žádný azylant anebo osoba s poskytnutou doplňkovou ochranou. V roce 2020 žádali tři žadatelé s mezinárodní ochranou. Dva z nich byli žadatelé s doloženým statutem osoby s doplňkovou ochranou a jeden žadatel s doloženým statutem

\footnotetext{
${ }^{30}$ KOSTRHƯNOVÁ, D. 2014. Uznávání zahraničního vzdělání. Př́íspěvek přednesený na 3.(8) ročníku mezinárodní konference CALL FOR PAPERS konané pod záštitou rektora Vysoké školy Karla Engliše. ISBN 978-80-86710-80-8.

Slavonic Pedagogical Studies Journal, eISSN 1339-9055, ISSN 1339-8660, Volume 10 Issue 2, 2021
} 
azylanta. V Ústeckém kraji byla podána 1 žádost azylanta a ostatní kraje v ČR nevedou evidenci zvlášt' o žadatelích s mezinárodní ochranou. ${ }^{31}$

\section{ZÁVĚR}

Stěhování národů anebo migrační vlny provázejí populace „,co je lidstvo lidstvem“. V souvislosti s globalizačním procesem a nepokoji v různých zemích světa dochází $\mathrm{k}$ větší či menší mezinárodní migraci. Zvýšený migrační proces je zaznamenán od roku 2001 válečným konfliktem V Kosovu, později od roku 2011 tzv. Arabské jaro, migrace osob z Blízkého a Středního východu (válka v Sýrii), Afganistán, Irák, migrace ze Severní Afriky. Vyvrcholením migrační krize je považován rok 2015.

V souvislosti s migrací je zaznamenána i migrace nelegální i zvýšená trestná činnost cizinců pramenící z konfliktu vzniklého z nespokojenosti a z mylného očekávání v nové zemi pobytu. Nelegální migrace přináší problémy, konflikty a zvýšenou finanční zátěž. Jednotlivé přijímající země tomu musí čelit. Dalším problémem může být jazyková bariéra, rozdílnost kultur, odlišná náboženství i rozdílné pohledy na společensko-hospodářský systém dané země. K tomu je třeba politická vůle, tolerance a nastavená pravidla. Jednotlivé země nesou zodpovědnost za nastavení migrační politiky. Vzhledem k tomu, že ČR je členem EU musí dodržovat jednotnou migrační politiku ostatních členských zemí. Souvislost s migrací má i uznávání vzdělání získané v cizí zemi. Uznávání zahraničního vzdělání (nostrifikace) slouží žadatelům, kteří migrují z jedné země do druhé, k legalizaci svého vzdělání získaného v cizí zemi pro účely studia na všech stupních vzdělávací soustavy ČR nebo pro získání pracovního povolení či získání živnostenského listu pro otevrení živnosti. Za posledních více než deset roků je v ČR pozorován nárůst žádostí o uznání vzdělání ve stovkách procent. Podíl na nárůstu migrace osob do ČR měl i vstup do Evropské unie v roce 2004.

Z uvedeného průzkumu vyplývají doporučení:

- Aby migranti (občané) z celého světa mohli žít v té zemi, kde se cítí bezpečně

- Aby migrující občané znali předem podmínky, se kterými se setkají po príchodu do ,nové“ země

- Aby migrační politika byla jednotná v zemích EU a pomáhala žadatelům $\mathrm{k}$ získání pracovních a studijních víz, žadatelům $\mathrm{o}$ mezinárodní ochranu

- Aby migranti (cizinci) znali podmínky uznávání vzdělání z cizí země v ČR

\footnotetext{
31 Vlastní zpracování na základě telefonického průzkumu v organizaci Člověk v tísni konzultace s Ondřejem Novotným, koordinátorem Programu migrace
} 
Vlivem migračních vln pozorovaných od roku 2011 od tzv. Arabského jara dochází i ke zvýšení a ovlivnění počtu žádostí o uznávání vzdělání z cizích zemí v ČR. Je zřejmé, že ČR ležící v srdci Evropy je pro východní, ale i západní svět zajímavá. ČR má nastavená pravidla k uznávání vzdělání ze všech zemí světa a také pravidla a zákony týkající se migrační politiky.

Je vidět, že propojení světů úzce souvisí s uznáváním vzdělání, i s pracovním trhem, mnohdy i s konfliktem formou jazykové bariéry. Ale lidé chtějí migrovat, chtějí poznávat jiné země, jiné národnosti, názorovou různorodost, dorozumívání se novými jazyky anebo jsou donuceni svoji zemi opustit. Je důležité, aby všichni lidé tolerovali odlišné zájmy, názory a schopnosti druhých (Tollarová a kol., 2013. p. 71). Rodíme se nerovní a svět tenduje $\mathrm{k}$ rasismu a xenofobii.

Př́nosem tohoto prríspěvku je přibližžení problematiky globální migrace spojené i s žádostmi o uznávání zahraničního vzdělání v ČR. Dále potom povědomí spojitosti získávání uznání vzdělání ze zahraničí s tím, že většina žadatelů o uznání vzdělání migruje z důvodu studia na českých univerzitách, kde je poskytováno kvalitní vysokoškolské vzdělání a o jeho studium je zájem.

\section{Bibliographic references}

KOSTRHUNOVA, D. 2014. Uznavani zahranicniho vzdelani. Prispevek predneseny na 3.(8) rocniku mezinarodni konference CALL FOR PAPERS konane pod zastitou rektora Vysoke skoly Karla Englise. ISBN 978-8086710-80-8.

PRUCHA, J. 2017. Vzdelavaci systemy v zahranicni: encyklopedicky prehled skolstvi v 30 zemich Evropy, Japonska, Kanade, USA. Wolters Kluwer. Praha. 320 p. ISBN 978-80-7552-845-2.

RAKOCZYOVA, M. - TRBOLA, R. 2008. Lokalni strategie integrace cizincu v CR I. 1. vyd. Praha: VUPSV. 74 p. ISBN 978-807-4160-066.

SISKOVA, T. 2001. Mensiny a migranti v Ceske republice. Portal, s.r.o. Praha. 188 p. ISBN 80-7178-648-9.

SISKOVA, T. 2008. Vychova k toleranci a proti rasismu. Portal, s.r.o. Praha. 280 p. ISBN 978-80-7367-182-2.

TOLLAROVA, B. - HRADECNA, M. - SPIRKOVA, A. a kol. 2013. Jsme lide jedne Zeme. 1. vyd. Praha. Portal, s.r.o. 260 p. ISBN 978-80-262-03766.

TRBOLA, R. - RAKOCZYOVA. M. 2010. Vybrane aspekty zivota cizincu v Ceske republice. 1. vyd. Praha: Vyzkumny ustav prace a socialnich veci. 121 p. ISBN 978-807-4160-677.

ZAMAROVSKY, V. 2005. Dejiny psane Rimem. Bratislava: Perfekt. 267 p. ISBN 80-8046-297-6.

ZAKON c. 326/1999 Sb., o pobytu cizincu na uzemi CR.

ZAKON c. 325/1999 Sb., Zakon o azylu.

ZAKON c. 111/1998 Sb., o vysokych skolach.

ZAKON c. 500/2004 Sb., Spravni rad. 
ZAKON c. 561/2004 Sb., o predskolnim, zakladnim, strednim, vyssim odbornem a jinem vzdelavani (Skolsky zakon).

Available online:

Prazsky studentsky summit/XX/EU/I. Asociace pro mezinarodni otazky pro potreby XX. rocniku Prazskeho studentskeho summitu. Imigrace na uzemi EU. AMO 2014.

Od revoluci arabskeho jara, https://www.e15.cz/zahranicni/od-revoluciarabskeho-jara-uplynulo-deset-let-zklamaly-lidem-se-zije-jeste-hur-1376360

Zasady migracni strategie dostupne

https://www.mvcr.cz/migrace/clanek/zasady-migracni-strategie.aspx

Obecne o migracni a azylove politice CR dostupne $\mathrm{z}$ :

https://www.mvcr.cz/migrace/clanek/obecne-o-migracni-a-azylove-politice-

ceske-republiky-obecne-o-migracni-a-azylove-politice-ceske-republiky.aspx

7 nejvetsich migracnich vln $\mathrm{v}$ historii dostupne $\mathrm{z}$ : https://epochaplus.cz/7nejvetsich-migracnich-vln-v-historii-odveka-honba-za-lepsi-budoucnosti/

Zdravotne humanitarni program dostupne

https://www.mvcr.cz/migrace/clanek/zdravotne-humanitarni-program-

medevac.aspx

Encyklopedie, dostupne z: https://encyklopedie.soc.cas.cz/w/Emigrace

Journals, ttps://journals.muni.cz/cepsr/article/view/4040/5278

Inkluzivni skola, dostupne z: https://www.inkluzivniskola.cz/o-migraci

Strategie migracni politiky, dostupne z:

https://www.mvcr.cz/migrace/clanek/strategie-migracni-politiky-ceske-

164 republiky.aspx

Migrace, dostupne z: https:/www.mvcr.cz/migrace/clanek/zasady-migracnistrategie.aspx

Informace pro skoly, dostupne z: https://www.mvcr.cz/clanek/informace-proskoly.aspx?q=Y2hudW09NQ\%3D\%3D

Mezinarodni ochrana, dostupne z:

https://www.mvcr.cz/migrace/clanek/nase-hlavni-temata-mezinarodni-

ochrana-mezinarodni-ochrana.aspx

Zadatele o mezinarodni ochranu, dostupne z:

https://www.migrace.com/cs/poradna/informace-pro-cizince/zadatele-o-

mezinarodni-ochranu

CIZINSKY, P. Overovani cizich listin. http://migraceonline.cz/cz/eknihovna/overovani-cizich-listin

Ondrej Novotny, koordinator Programu migrace Clovek v tisni

Ing. Bc. Dagmar Kostrhůnová, MBA

AMBIS vysoká škola, a.s.

Šujanovo náměstí 356/1

60200 Brno

Czech Republic

38324@mail.ambis.cz 